\title{
Reality and Mythology, Convention and Novelty in T. S. Eliot's The Waste Land
}

\author{
Walid Ali Ziater \\ Taibah University, Saudi Arabia
}

\begin{abstract}
Eliot's Waste Land, its implications, sources, his treatment of myth, reality, convention and novelty, has received a huge bulk of criticism among Eliot's scholars whose views of the poem are divided into two categories: positive and negative. This article examines these terms against Eliot's fundamental approaches to an individual work of literature in his "Tradition and Talent" essay and the application of the "objective correlative" when applying criticism to the poem. The article argues that Eliot employed myth, allegory and symbols in a very novel way to connect the past with the present; he could criticize without direction and educate and entertain his readers with host of interpretations applicable to the now and then. Another important key to understand Eliot's Waste Land is that his objective correlative is what links the poem which may look fragmentary, but in fact complete in thought with the help of this technique. By so doing Eliot has gained a statutes among the modernists in the realm of poetry - new modes of writing poetry.
\end{abstract}

Index Terms-Eliot, Myth, reality, convention, novelty

\section{INTRODUCTION}

Eliot's writings whether in poetry, drama, philosophy or criticism are read and quoted on a large scale. These writings have proved, among the intellectuals and to a lesser degree among the average readers, to help grasp "our social world, and awareness of its conditions." Since Eliot was a critic, a poet, a dramatist and above all a modern thinker, his creative art has gained a status among literary circles particularly his treatment of mythology in his great works such as The Waste Land He projects myth on reality to avoid directness .Calder (1987) states in the introduction to his book New Readings: "Eliot's poetry is bifocal; it can be read in relation to $20^{\text {th }}$ century history" (p. 6). This statement of fact applies to all writers. Who can write without some kind of influence, reference or reflection of his or her life, experience, time, place and what have you. These are the building blocks in the creative writing of a man of letters in any given time since Homer to Eliot to our 21th century. However, Eliot's greatness lies in his treatment of myth and reality, convention and novelty which makes a man of letters distinguished and an icon for the his age.

By way of introduction to Eliot's time, the twentieth century saw great changes. The first two decades of the $20^{\text {th }}$ century Europe as well as America witnessed eruption of wars and revolutions, whose consequences were tragic not only to the ordinary man but also to the intellectuals like T.S. Eliot (1888-1965) and his mentor Ezra Pound who both came from USA to settle in Britain. It was such a short time after they had left their native land, they voiced different perspectives of literature, enriching the literary scene with novel modes of literature. They were considered revolutionary compared to conventional literary figures. Between 1910 and 1922 Eliot was having personal problems; his marriage was unhappy one. Pinion (1986) referred to a biographical note when Eliot reduced the five lines to three "on the closed car and the game of chess in The Waste Land referring to Vivienne, Eliot's wife" (p.102).

Under the firelight, under the brush, her hair

Spread out in fiery points

Glowed into words, then would be savagely still.

What these lines uncover a scene from his life with Vivienne is important to the allusions in this poem whether, realistic, mythological, allegorical or symbolic. Eliot's treatments of these elements are keys in the poem to the reader or the critic. When Eliot wrote the Poem, he made it symbolic and allegorical by the employment of mythology to represent the political, philosophical, social and religious aspects in his time, a nut shell poem representing the age.

In addition to all that, one cannot read the poem without drawing on the occasion on how Eliot met his friend and mentor Ezra Pound, Calder (1987) specifies the time when Eliot was in London in 1921 he met Pound, the editor of The Waste Land and showed him his unfinished poem; Eliot wrote the final sections of the poem when he was in Switzerland." It was said that Pound encouraged Eliot "to cut away lengthy narrative and satiric consequences in different voices" (p.51). Pound's changes on the original poem were discovered in New York after being lost for many decades.

With Pound's massive cuts to the poem, Eliot became confused by Pound's heavy editing of the poem; he did not know whether he had written a single poem or a host of many. Pound had persuaded Eliot to publish it. Then it appeared in complete sequence in a single issue of the Dial, a USA magazine (November 1922). However, Eliot first published it in book form, published by Boni and Liveright in New York USA (December 1922). "In September 1923, it appeared in Woolf's Hogarth Press in London. It is said that Eliot provided the notes to avert charges of plagiarism 
and to expand the poem into a book"(p52). These biographical notes above mentioned are facts or keys serving as synopsis to understand the background of the poem.

\section{The Structure OF The Poem}

The Waste Land is along poem of four hundred thirty four lines; it consist of five parts: Burial of the Dead, A Game of Chess, The Fire sermon (the longest part), Death by Water (the shortest part) and What the Thunder Said. The first line of the poem alludes to Chaucer's Canterbury Tales Prologue; Eliot starts the poem with real depiction of seasons, London Bridge. Then he draws on a mythological character Tiresias the blind and then he goes back to reality, London Bridge. These allusions can be seen in the following extracts from the poem.

April is the cruelest month, breeding

Lialacs out of the dead land, mixing

Memory and desire, stirring

Dull roots with spring rain.

Winter kept us warm, covering

Summer surprised us, coming over the Stambergersee

With a shower of rain; we stopped in the colonnade,

And went in the sunlight, into the Hofgarten

And drank coffee, and talked for an hour. (The Burial of the Dead)

Now Eliot shifts to the description of London and its bridge and inhabitants.

Unreal city,

Under the brown fog of a winter dawn,

A crowd flowed over London Bridge so many,

I had not thought death had done so many. (The Burial of the Dead)

Then after that Eliot depicts a mythological character Tiresias, seen by many critics as the protagonist of the poem, who serves as a symbol to connect past with the present.

At the violet hour, when the eyes and back

Turn upward from the desk, when the human engine waits

Like a taxi throbbing waiting,

I Tiresias, though blind, throbbing between two lives,

Old man with wrinkled female breasts, can see

At the violet hour, the evening hour that strives

Homeward, and brings the sailor home from the sea (The Fire Sermon)

In addition to all, Eliot in the couplet below connects all places mentioned above in the poem and it serves as a logical conclusion to his vision of seeing the fall of London Bridge as a symbolic fall of western civilization.

Shall I at least set my lands in order?

London Bridge is falling down falling down falling down (What the Thunder Said)

\section{CRITICISM OF THE POEM}

Commenting on these lines and others of the poem, Wilson (1922) in his article entitled "The Poetry of Drouth", first published first in 'Dial' and then appeared in MICHAEL NORTH's T.S. Eliot THE WASTE LAND, argues that Eliot "uses The Waste Land as a concrete image of a spiritual drouth." His argument is based on the following objections, which Wilson in his article touches briefly on Eliot as " is one of our only authentic poets and that The Waste Land

For this new poem--which presents itself as so far his most considerable claim to eminence--not only recapitulates all his earlier and already familiar motifs, but it sounds for the first time in all their intensity, untempered by irony or disguise, the hunger for beauty and the anguish at living which lie at the bottom of all his work. (p. 140).

For the first reading of the citation, it may sound contradictory but in reality, it reveals harsh criticism.

Another objection Wilson finds in the poem is that Eliot's symbolism was derived from Miss Jessie L. Weston's book From Ritual to Romance. As I mentioned above, who can write without relying on some sources, references or allusions? Absolutely no one can do that. Wilson's accusations have not stopped there, he contends that Eliot's mind "finds itself looking out upon the present with the prouder eyes of the past and which loves to make its oracles as deep as the experience of the race itself by piling up stratum upon stratum of reference, as the Italian painters used to paint over one another" ((P. 140). This criticism is positive rather than negative. It is impossible for a poet Like Eliot not drawing on any reference in the past and transforming it to his poem; this allusion connects those who had lived in the past and those who still live in the present; by alluding to the past, Eliot is assuming the role of continuity, which many thinkers, poets, dramatists and philosophers in the western civilization still presume for ages since the Greeks, Romans till the present time.

\section{IV. "TRADITION AND THE INDIVIDUAL TALENT"}


However, I think the best way to read Eliot's Waste Land requires the reader to, first, read Eliot's essay "Tradition and the Individual Talent" (1919) in which he voices his basic principles of criticism. Then, his tenets must be taken into consideration while evaluating or criticizing his poetry, particularly The Waste Land. Below an extract taken from the essay which shows a procedure to follow when evaluating a particular or individual piece of art, a book and so on, bearing in mind the mature production or productions of a poet or artist than his immature one or ones. This extract of the essay which appears in David Lodge's 2Oth Century Literary Criticism: A Reader

One of the facts that might come to light in this process is our tendency to insist, when we praise a poet, upon those aspects of his work in which he least resembles anyone else. In these aspects or parts of his work we pretend to find what is individual, what is the peculiar essence of man. We dwell with satisfaction upon the poet's difference from his predecessors, especially his immediate predecessors ..., but the most individual parts of his work may be those in which the dead poets, his ancestors, assert their immortality most vigorously. And I do not mean the impressionable period of adolescence, but the period of full maturity. (Lodge, 1972, p 71).

Clearly this citation lays down principles for criticism when we read a particular work of literature of a poet and his and her talent for mastering this work. Another aspect from Eliot's essay which tackles the implications of tradition in literature is the timeless, the continuity but with novelty which makes the poet or the artist original rather than a copy of tradition of literary conventions. On this issue Eliot argues that: "Tradition should positively be discouraged ...; and novelty is better than Repletion. Tradition is a matter of much wider significance. It cannot be inherited, and if you want it you must obtain it by great labor .Eliot adds that tradition "involves, in the first place, the historical sense, which we may call nearly indispensible to anyone. and "it" involves apperception, not only of the pastness of the past, but of its presence and it compels a man to write not merely his own generation in his bones, but with a feeling that the whole of the literature of Europe from Homer within it the whole of literature of his own country has a simultaneous existence and composes a simultaneous order." This historical sense, a combination of "the temporal and of the timeless and of the temporal, is what makes a writer traditional ... at the same time what makes a writer most acutely conscious of his place in time, of his own contemporaneity" (p.72).

Such continuity with the past by invoking literary figures from distant past has made Wilson disregard Eliot's poem when he alludes to Eliot's sources: "the Vedic Hymns, Buddha, the Psalms, Shakespeare, Virgil, Dante, Miss Weston's book," and Eliot's own earlier poems"(142). One may wonder about the objectivity of Wilson's criticism when being harsh in evaluating Eliot's poem as work of literature not as a document of history; Wilson has denied a poet as Eliot his imagination to treat mythology as he pleases not as Wilson would.

It seems that not only critic Wilson has harshly criticized the poem but also Hay (1982) declares "The poem is Eliot's first long philosophical poem and it can be read simply as it was written, as a poem of radical poem and negation, urging every human desire to be stilled except the desire for self surrender, for restraint, and for peace" (p.48). This criticism is too general, and we cannot blame Eliot for writing in such away; for the reader's best knowledge Eliot was writing a new genre of poetry. Thus the above mentioned attacks of his poem are based on lacking the comprehension of this new genre whose objective correlative is basic to understanding Eliot's poetry.

\section{The ObJective Correlative}

Sharma (2018) states: "Objective Correlative is a term popularized by T.S. Eliot in his essay on 'Hamlet and His Problems' to refer to an image, action, or situation - usually a pattern of images, actions, or situations - that somehow evokes a particular emotion from the reader without stating what that emotion should be (web).

On the application of the objective correlative to The Waste Land Matthiessen (2003) writes:

It should now also be clear that his understanding of the value of the objective correlative was what caused Eliot to base the dramatic lyric intensity of The Waste Land in the externalized structure of parallel myths. It also led him to give the poem even further focus sifing it through the eyes of a central observer, Tiresias - a device which Eliot has learned in part from Henry James's use of Strether in The Ambassador. As Eliot states in a note. "What Tiresias sees, in fact, is the substance of the poem. And Tiresias is the exact symbol for such haunting inclusion consciousness: only Tiresias, who had experienced life both as a man and a woman, who, though blind, possessed the torturing faculty of being able to foresee the future, could contain in his vision the ranges of life in a great metropolis (p.86).

\section{INTERSEXUALITy, Mythology AND SyMBOLISM}

Audhuy (1985) argues that Eliot's Waste Land has a lot on common with Fitzgerald's' The Great Gatsby. Symbols of analogy between the two works are Owl-eyes in Gatsby and Tiresias in The Waste land who is blind but sees into the future. She says When the Owl-eyes man appears, the emphasis is on seeing, through distortion and confusion. In The waste Land Tiresias is blind but a soothsayer of antiquity who had figured in Oedipus Rex, a very important symbol for Freud in psychological analysis. Tiresias is only a spectator, not character, but the most important symbol in the poem (p.117). I think both Eliot and Fitzgerald have invented new roles for their characters to play. The former is fictional but functional, the latter mythological but suggestive. That is why Audhuy's reading of the poem is profound and has also given credit to the poem by applying modern criticism rather than conventional approaches to literature. Eliot's imagery in the poem is strikingly new by the application of the objective correlative technique, which is key component in 
understanding Eliot's poetry. In fact, there are other key features in Eliot's poetry such as myth, symbols, allegory and others; all these have been summoned in Eliot's Waste Land.

The myth of Greek tragedy represented by Tiresias is an allusion and symbol for the foreshowing of what is going to happen as a bad omen. This treatment is an addition to Eliot's vision of mythological characters. Again Fitzgerald has used the Owl-eyes man as a symbol of watching but doing nothing, which is in reality means that a host of things that happen in the society where the authorities take no actions against. No wonder that both writers have the same vision as allegory of political and social implications This tackling of allegorical aspects may "quicken the destruction of the modern world where power rules over everything and the weak are to suffer their fate at the mercy of the strong and powerful" (Guerin, p.66) I think Guerin is right in his conclusion that "the intricate links of the many shards of experience drawn from both the ancient and the modern worlds are linked by the pervasive Tiresias"(P .67).

On this paradoxical treatment of life, Brooks (1971) points out that The Waste Land is "built on a major contrast between two kinds of life and two kinds of death. Life devoid of meaning is death; sacrifice, even the sacrificial death, may be life-giving, an awakening to life. The poem occupies itself to a great extent with this paradox." (p.8) in this vein, Drew (1949) argues that

the Grail legend had transposed the older symbols of initiation ceremonies into their Christian forms ... into the ordeals of the knights who set out to achieve the cure for the king and salvation for the land through self-purification (p.62).

Drew has more or less provided some insights or interpretation of Grail legend which may very well apply to Eliot's Waste Land. One may wonder who will bring such things in the world. There is some foreshadowing for the second coming of Christ according to Christian doctrine. Then Eliot is right to turn his poem into a host of readings and it is left to the educated and the average reader to interpret the poem according to his or her knowledge of the world and personal experience.

\section{IMAGERY}

Finally, Pinion (1986) describes the imagery and scenes in The Waste Land as lacking "contextual narrative. Scenes from life are presented in symbolical terms to communicate deeper meaning to form a whole by a response in feeling and attitude which might metaphorically be described as a 'music of ideas'" (p.120). Pinion after having analyzed the poem, he suggested that imagery in the poem be taken into consideration. On this particular aspect of the poem he writes:

the imagery in The Waste land is biblical in origin. It expresses Eliot's apprehension that with the decay of the Christian faith no religion would succeed it, and humanity would become spiritually dead). These views only reflect the early poetry of Eliot before he converted and received in the Church of England and then became a British citizen on 2 November 1927" (pp.35-36).

This biographical note adds to the understanding of Eliot's involvement in religious upbringing and his faith. Calder considers Tiresias a representative of both sexes; a voice of Buddha who preaches against lust and Eliot echoes St Augustine's rejection of sensual temptation" (p.57) Another point to consider is that according to Calder: The Fisher King still sits fishing and The Waste Land ends in chaos and madness. It echoes the wars and the Russian revolution in the beginning of the $20^{\text {th }}$ century. Calder suggests that Eliot's is struggling like the Victorians poets, he wants to find a way out from this chaos and anarchy in the world" (p.64). What Calder has just suggested is the reality which Eliot depicts in The Waste Land: myth of the Fisher King and its projections on the present situations throughout Europe and America. People then were suffering from social instability, integration and above all spiritual emptiness. These are the musings which Eliot treated in The Waste Land. It is the paradox of his age that he transformed in his poem.

\section{CONCLUSION}

From the above one can conclude that early Eliot's master piece The Waste Land should be viewed as such within the context of Eliot's knowledge, experience of the world. However, Eliot's later life and poetry should be taken into consideration when evaluating such great poet, critic and thinker; his "Tradition and Talent essay, should receive equal attention when evaluating his poetry. His poetry is novel. That is why he discouraged tradition of static convention. His treatment of classic literature was a means to project on the present. To do so he employed myth, allegory and symbols in a very novel way to connect the past with the present; he could criticize without direction and educate and entertain his readers with host of interpretations applicable to the now and then. Another important key to understand Eliot's Waste Land is that his objective correlative is what links the poem which may look fragmentary, but in fact it is complete in thought with the help of this technique.

\section{REFERENCES}

[1] Audhuy, L. (1986). The Waste Land Myth and Symbols in The Great Gatsby". In Harold Bloom(ed), Modern Critical Interpretations: F. Scott Fitzgerald's The Great Gatsby. New York: Chelsea House Publishers, 109-122.

[2] Brooks, C. RAJAN, B. (1971). The waste Land: An Analysis. In B. Rajan (ed). T. S. Eliot: A Study of His Writings by Several Hands. London: Denis Dobson, 7-36. 
[3] Calder, A. (1987). New Readings: T. S. Eliot._Britain: The Harvester Press.

[4] Cleanth, B. (1971). The Waste Land: An Analysis. In B. Rajan (ed), T.S. Eliot: A study of his Writings by several hands. Ed.. London: Latimer, 7-36.

[5] Drew, E. (1949). T. S. Eliot: The Design Of His Poetry. New York: Charles Scribner's Sons.

[6] Eliot, T.S. (1972). Tradition and the individual talent. In D. Lodge, (ed),. $20^{\text {th }}$ Century literary Criticism: A Reader. London: Longman, 71-77.

[7] Hay, E. K. (1982). T. S. Eliot's Negative Way. USA: Harvard University Press.

[8] Kermode, F. \& J. Hollander (19773) Eliot, T. S. (1973). The Waste Land. In The Oxford Anthology of English Literature (vol. 2). New York: Oxford University Press, 1983-1908.

[9] Matthiessen, F. O. (2003). "The Objective Correlative". In Harold Bloom (ed), T.S. Eliot: Bloom's Harold's Bio Critiques. Introduction by Harold Bloom. USA, Philadelphia: Chelsea House Publishers, 83-97.

[10] Pinion, F. B. (1986). A T.S. Eliot Composition: Life and Works .London: The Macmillan.

[11] Sharma, K.N. (2018). "Objective-Correlative Literary Term. Web Bachelorandmaster https://www.bachelorandmaster.com/literaryterms/objective-correlative. (accessed 20/4/2018).

[12] Wilson,E,Jr. (2001). The Poetry of Drout In M. North (ed), T. S. Eliot The Waste Land. New York: W.W. Norton,. 140-45.

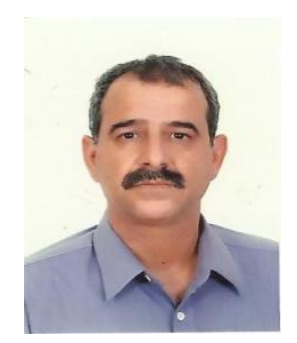

Walid A. Zaiter was born in Emrawa, Jordan, on the $2^{\text {nd }}$ of April 1960. He received the following degrees in literature, languages and language teaching as EFL. My last degree was a PhD of English literature at Jordan University in 2016; MA in English Language \& Literature at Jadara University, Irbid- Jordan in 2011. He earned his bachelor degree in English Language at Yarmouk University, Irbid-Jordan in 1983.

He taught at Jordanian Air Force Schools and Colleges American Language Courses, 1983-2000; Full time-instructor and part time- translator during the same period of time; he wrote booklets in English to facilitate English teaching; evaluated curriculum and personnel. He taught at Sultanate of Oman Technical Colleges on different English language skills: writing, communication, listening, reading and grammar, 20012009; he attended Language conferences and participated in one; he staged many English sketches and wrote a few; he taught American language Course at Prince Hashim Ibn Al Hussein School for Special Operations in 2011. Now he holds a position of assistant professor of English literature at Taibah University, Al Madina- Al Ulla Branch, Saudi-Arabia, Department of Languages and Translation. 